\title{
Tingkat Toksisitas dari Beberapa Ekstrak Tanaman Paku Kaki Tupai (Davalia denticulate)
}

Rudi Hendra1,3,", Rohimatul Khodijah'1, Muhammad Afham ${ }^{1}$, Rachel Fachira ${ }^{1}$, Neri Sofiyanti², Hilwan Yuda Teruna ${ }^{1,3}$

\author{
${ }^{1}$ Jurusan Kimia, FMIPA Universitas Riau, Pekanbaru \\ 2Jurusan Biologi, FMIPA, Universitas Riau, Pekanbaru \\ ${ }^{3}$ Scientific Consortium of Drug Discovery and Development, Universitas Riau, Pekanbaru \\ *Email korespondensi: rudi.hendra@lecturer.unri.ac.id
}

(Submit 15/03/2019, Revisi 05/09/2019, Diterima 20/12/2019)

\begin{abstract}
Abstrak
Tumbuhan paku kaki tupai (Davalia denticulata) merupakan salah satu tumbuhan paku epifit yang tumbuh pada kelapa sawit dan digunakan untuk mengurangi kandungan asam urat.. Beberapa spesies dari genus ini dilaporkan telah digunakan sebagai obat tradisional untuk mengobati penyakit infeksi dan juga kanker di Taiwan. Tetapi, pada spesies ini kandungan metabolit sekunder dan tingkat toksisitasnya belum di laporkan. Penelitian ini bertujuan untuk menguji tingkat toksisitas dari beberapa ekstrak dari tumbuhan paku kaki tupai. Tumbuhan dikering-anginkan kemudian diekstraksi dengan metode maserasi dengan pelarut metanol, etil asetat dan n-heksana. Masing-masing ekstrak dilakukan pengujian toksisitas dengan menggunakan metode Brinne Shrimp Lethality Test (BSLT). Pada penelitian ini didapatkan empat ekstrak dari pelarut yang berbeda-beda. Masing-masing ekstrak dilakukan pengujian BSLT. Hasil dari pengujian ini di dapat bahwa ekstrak etil asetat memiliki toksisitas yang tinggi dengan LC50 sebesar $119,8 \mathrm{ppm}$ diikuti oleh ekstrak methanol dengan LC $_{50}$ sebesar $215,5 \mathrm{ppm}$. Sedangkan ekstrak heksan memiliki nilai $\mathrm{LC}_{50}>1000 \mathrm{ppm}$. Berdasarkan laporan yang ada, jika hasil BSLT menunjukkan bahwa ekstrak tumbuhan bersifat toksik maka dapat dikembangkan ke penelitian lebih lanjut untuk mengisolasi senyawa sitotoksik tumbuhan sebagai usaha pengembangan obat alternatif anti kanker. Pengujian toksisitas dari tanaman ini didapatkan bahwa ekstrak etil asetat dan methanol memiliki tingkat toksistas yang tinggi. Oleh karena itu diperlukan pengujian isolasi senyawa metabolit sekunder dari ekstrak tersebut dan dilakukan pengujian toksisitasnya sehingga diharapkan memiliki senyawa yang bersifat antikanker.
\end{abstract}

Kata kunci: Tumbuhan paku kaki tupai, toksisitas, BSLT

\section{Outline}

- Pendahuluan

- Metode

- Hasil dan Pembahasan

- Kesimpulan

- Ucapan Terima Kasih

- Daftar Pustaka 


\section{Pendahuluan}

Tanaman Paku kaki tupai (Davallia denticulata) adalah salah satu tanaman paku epifit yang paling banyak tumbuh di pohon sawit ${ }^{1}$. Beberapa spesies dari genus Davallia (Davalliaceae) secara luas digunakan dalam pengobatan tradisional karena efek farmakologisnya sebagai antioksidan ${ }^{2,3}$, antiosteoporosis ${ }^{4}$ dan anti asam urat ${ }^{3}$. Beberapa spesies dari genus Davallia, seperti $D$. lavanone, $D$. mariesii, dan $D$. solida digunakan sebagai Gusuibu, salah satu pengobatan tradisional China yang telah diuji memiliki manfaat untuk peradangan, kanker, penuaan, dan cedera tulang ${ }^{5}$.

Komponen kimia genus Davallia telah banyak dipelajari. Secara total lebih dari 80 senyawa diisolasi dan diidentifikasi termasuk triteroidoid, seskuiterpenoid, flavanon, flavan-3-ols, xanton dan proantosianidin². Cui et al. (1990) mengisolasi akar D. mariesii dan diperoleh beberapa senyawa yaitu asam kafeat, asam 4-O- $\beta$-D-glukopiranosil kafeat, asam 4-O- $\beta$-D-glukopiranosil-p-kumarat, davallialakton, dan ( \pm )-eriodiktiol7-O- $\beta$ D-glukuronida. ${ }^{6,7}$

Tumbuhan paku kaki tupai adalah salah satu tumbuhan paku yang belum banyak dikaji secara intensif, namun mempunyai potensi yang cukup besar di Indonesia, yang habitatnya umum dijumpai sebagai tumbuhan epifit di pohon sawit. Oleh karena itu, dalam penelitian ini, dilakukan pengujian awal untuk mengetahui tingkat toksisitas dari ekstrak tanaman ini dengan menggunakan beberapa pelarut.

\section{Metode}

Adapun bahan yang digunakan pada penelitian ini adalah tumbuhan paku kaki tupai $(D$. denticulata), n-heksana, etil asetat, metanol, akuades, Artemia salina, dan bahan uji fitokimia.

\section{A. Ekstraksi}

Sebanyak $10 \mathrm{~kg}$ aerial parts tumbuhan paku kaki tupai diperoleh serbuk sampel sebanyak $3 \mathrm{~kg}$ yang diekstraksi dengan cara maserasi menggunakan pelarut $\mathrm{n}$ heksana, etil asetat dan metanol. Maserasi dilakukan selama 3×24 jam. Setiap 1×24 jam ekstrak disaring dan masing-masing filtrat ditampung. Sebelum disaring sampel diultrasonifikasi selama 1 jam. Kemudian filtrat tersebut dipekatkan dengan rotary evaporator pada suhu $40^{\circ} \mathrm{C}$ sehingga diperoleh ekstrak kasarnya. Ekstak kasar total $\mathrm{n}$ heksana, etil asetat dan metanol ditimbang dengan timbangan analitik.

\section{B. Fitokimia}

Pengujian fitokimia dilakukan untuk mengetahui terdapatnya senyawa alkaloid, flavonoid, terpenoid/steroid, dan saponin ${ }^{8}$.

C. Uji Toksisitas (Brine shrimp lethality test)

Uji toksisitas digunakan dengan metode brine shrimps lethalty test (BSLT). ${ }^{9}$

\section{Hasil dan Pembahasan}

Sampel yang digunakan pada penelitian ini adalah tumbuhan paku kaki tupai $(D$. denticulata) yang diambil di batang pohon kelapa sawit yang terdapat di Halaman 
Fakultas Pertanian, Universitas Riau, Pekanbaru. Tumbuhan ini juga telah diidentifikasi oleh Kepala Laboratorium Botani Jurusan Biologi FMIPA Universitas Riau. Hasil identifikasi kandungan kimia tumbuhan paku kaki tupai dapat dilihat pada Tabel 1.

Tabel 1. Hasil skrining uji fitokimia tumbuhan paku kaki tupai. (Hasil dijabarkan dengan tanda (+) menunjukkan adanya kandungan senyawa dan (-) tidak ada kandungan senyawa).

\begin{tabular}{|c|c|c|}
\hline No & Uji Fitokimia & Hasil \\
\hline 1 & Alkaloid & - \\
\hline 2 & Flavonoid & - \\
\hline 3 & Saponin & + \\
\hline 4 & Terpenoid/Steroid & + \\
\hline 5 & Fenolik & + \\
\hline
\end{tabular}

Pada pengujian toksisitas dengan menggunakan metode BSLT, di dapat data pada table 2 di bawah:

Tabel 2. Hasil uji Toksisitas ekstrak D. denticulata dengan Metode Brine Shrimp Lethality Test (BSLT)

\begin{tabular}{|c|c|}
\hline Ekstrak & $\begin{array}{c}\mathrm{LC}_{50} \\
(\mu \mathrm{g} / \mathrm{mL})\end{array}$ \\
\hline n-Heksana & $>1000$ \\
\hline Etil asetat & 119,8 \\
\hline Metanol & 215,5 \\
\hline
\end{tabular}

Sampel yang digunakan pada penelitian ini adalah tumbuhan kaki tupai (D. denticulata) yang diambil di batang pohon kelapa sawit. Sampel dilakukan uji fitokimia terlebih dahulu untuk menentukan golongan senyawa metabolit yang terkandung didalamnya. Berdasarkan Tabel 1 diperoleh bahwa tumbuhan $D$. denticulata memiliki senyawa metabolit sekunder golongan flavonoid, terpenoid/steroid, saponin dan fenolik.

Uji toksisitas metode Brine Shrimp Lethality Test (BSLT) dilakukan untuk mengetahui aktivitas toksik dari masing-masing ekstrak. LC $_{50}$ adalah nilai yang menunjukkan kemampuan konsentrasi yang dapat mematikan $50 \%$ populasi larva udang. Nilai $\mathrm{LC}_{50}$ ini didapatkan dengan cara memasukkan nilai $y=5$ ke dalam persamaan regresinya sehingga didapatkan nilai $\mathrm{LC}_{50}$ masing-masing ekstrak dapat dilihat pada Tabel 2 . Suatu senyawa atau ekstrak dikatakan memiliki aktivitas toksik jika mempunyai nilai $\mathrm{LC}_{50}<$ $1000 \mathrm{ppm}$. Berdasarkan hasil analisa yang telah dilakukan untuk aktivitas toksisitas ekstrak n-heksana memiliki nilai $\mathrm{LC}_{50}>1000$ ppm. Sedangkan pada ekstrak etil asetat dan metanol memiliki sifat toksik dengan $\mathrm{LC}_{50}<1000 \mathrm{ppm}$ (Tabel 2). Berdasarkan nilai $\mathrm{LC}_{50}$ pada ekstrak etil asetat dan metanol menunjukkan potensi aktivitas toksisitas yang sangat baik yang terhadap hewan uji larva $A$. salina Leach karena nilai LC $_{50}$ kurang dari $1000 \mathrm{ppm}$. Mekanisme kematian larva ini diduga karena potensi kandungan senyawa yang terdapat di dalam masing-masing ekstrak. Sehingga kedua ekstrak ini dapat digunakan sebagai dasar dalam proses isolasi untuk mendapatkan senyawa murni yang memiliki potensi sebagai kandidat dalam bioaktivitas lainnya. 


\section{Kesimpulan}

Pengujian toksisitas dari tanaman ini didapatkan bahwa ekstrak etil asetat dan methanol memiliki tingkat toksistas yang tinggi. Oleh karena itu diperlukan pengujian isolasi senyawa metabolit sekunder dari ekstrak tersebut dan dilakukan pengujian toksisitasnya sehingga diharapkan memiliki senyawa yang bersifat antikanker.

\section{Ucapan Terima Kasih}

Penulis mengucapkan terima kasih kepada LPPM Universitas Riau yang telah mendukung penelitian ini (Kontrak No. 733/UN.19.5.1.3/PP/2018)

\section{Daftar Pustaka}

1. Eka Indra H, Sofiyanti N, Iriani D. DAVALLIACEAE (PTERIDOPHYTA) DI BUKIT BATU KABUPATEN BENGKALIS-SIAK PROVINSI RIAU.

2. Cao J, Xia X, Dai X, Wang Q, Xiao J. Chemical composition and bioactivities of flavonoids-rich extract from Davallia cylindrica Ching. Environ Toxicol Pharmacol. 2014;37(2):571-9.

3. Chen C-Y, Huang C-C, Tsai K-C, Huang W-J, Huang W-C, Hsu Y-C, et al. Evaluation of the antihyperuricemic activity of phytochemicals from Davallia formosana by enzyme assay and hyperuricemic mice model. Evid Based Complement Alternat Med. 2014;2014.

4. Ko Y-J, Wu J-B, Ho H-Y, Lin W-C. Antiosteoporotic activity of Davallia formosana. J Ethnopharmacol. 2012;139(2):558-65.

5. Cheng A-S, Chang W-C, Cheng Y-H, Chen K-Y, Chen K-H, Chang T-L. The effects of Davallic acid from Davallia divaricata Blume on apoptosis induction in A549 lung cancer cells. Molecules. 2012;17(11):12938-49.

6. CUI C-B, TEZUKA Y, KIKUCHI T, NAKANO H, TAMAOKI T, PARK J-H. Constituents of a fern, Davallia mariesii Moore. I. Isolation and structures of davallialactone and a new flavanone glucuronide. Chem Pharm Bull. 1990;38(12):3218-25.

7. CUI C-B, TEZUKA Y, YAMASHITA H, KIKUCHI T, NAKANO H, TAMAOKI T, et al. Constituents of a fern, Davallia mariesii Moore. V. Isolation and structures of Davallin, a new tetrameric proanthocyanidin, and two new phenolic glycosides. Chem Pharm Bull. 1993;41(9):1491-7.

8. Harbone J. Metoda fitokimia, penuntun cara modern menganalisis tumbuhan.(edisi ke-2). Diterjemahkan oleh K Padmawinata danl Soediro ITB, Bandung. 1987.

9. Meyer B, Ferrigni N, Putnam J, Jacobsen L, Nichols D, McLaughlin J. Brine shrimp: a convenient general bioassay for active plant constituents. Planta Med. 1982;45(1):31-4. 